\title{
Odvisni od podob?
}

Pomembna preobrazba danajšnjega sveta, $k i$ povzroča potrebo po izobraževanju in vzgoji odraslih, je tudi neoliberalizem. Ta ne prenaša meja. Prizadeva si za razkroj že zelo starih kolektivnih struktur kot so družina, sindikati, stranke in nasplošno tudi kultura. Poskuša ustvariti novega post-modernega človeka, ki naj bi ne bil kritičen. $K$ temu naj bi pripomogla televizija, $v$ mnogočem pa tudi podjetniško izobraževanje odraslih, še posebej tisto, ki sledi določilom "franšiznih pogodb".

Vpliv televizije na otroka in posledično na učenje odraslega skozi življenje se prične zelo zgodaj. To je novo antropološko dejstvo. Še več, otrok spremlja televizijo še preden spregovori. Še preden spregovori je njegova zavest prepolna vidnih podob. Zaradi televizije se manjša vloga družine in njene prenašalske vloge $v$ kulturi, $k i$ gre, ali bolje je šla, iz roda v rod. Televizija je prevzela vzgojno vlogo, ki je nekoč pripadala staršem. Posledice je čutiti $v$ človekovem simbolnem in psihičnem svetu. Uporabljati simbole, govoriti, pomeni pripovedovati drugemu zgodbe, preneseti na drugega prepričanja, posredovati mu lastna imena, običaje, naloge, prenesti nanj znanje, čustva, uvesti ga $v$ družbena razmerja, predvsem pa pomeni posredovati drugemu besedo oziroma govor. Od roda do roda se tako pretaka sposobnost govora. Če, denimo, dovolimo študentom, da sami ustvarjajo zapiske predavanj, pri tem uporabljajo miselne postopke, še posebej analizo. Če uporabljamo "power point projekcijo", jih podredimo svoji konceptualizaciji teme in načnemo njihovo sposobnost ustvarjanja lastnih predstav, ob tem pa zavremo transformativno učenje. Televizija spodkoplje pogovor med rodovi. V izobraževanju

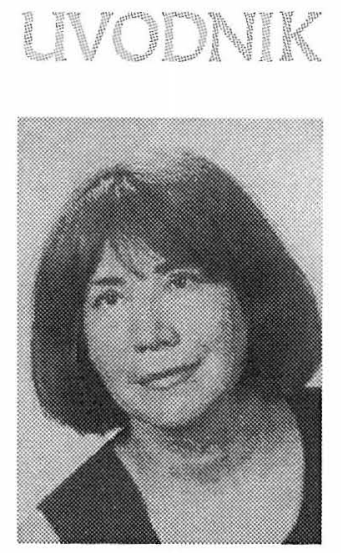

dr. Dušana Findeisen odraslih pa te, nekdaj naravne vezi med njimi ni lahko nadomestiti, četudi si za to prizadevamo z medgeneracijskimi programi učenja, izobraževalnimi tabori za družine, univerzo za tretje življenjsko obdobje, študijskimi krožki, kjer se srečujejo različne generacije odraslih, ipd.

Še več, zunanje podobe, ki nas spremljajo vsepovsod, tudi na velikih lepakih, postanejo naše notranje podobe, kopičijo in vrstijo se tako brez reda in povezave, postavljajo nas $v$ odvisen položaj. To še pripomore $k$ temu, da manj obvladujemo simbolične kategorije prostora, časa, osebe. To vnaša zmedo v naše zaznavanje simbolov, sproža fantazme. Načne našo usposobljenost za diskurz.

Ali učenje z razmišljanjem pripada le družbenim elitam?

To, česar si mladi, pogosto tudi odrasli, želijo, ni razmišljanje, ni uporaba simbolov, ni abstraktno mišljenje, ni intelektualizacija, marveč interakcija. To pomeni, da ni potrebe, da bi mladi, in nekateri odrasli, neprestano opuščali svoje misli, svoje zorišče in se prilagajali misli mentorja, ki ima bolj posplošene in navadno bolje oblikovane in tematizirane misli ... Mnogi sodobni didaktični postopki in sodobna učna tehnologija pripomorejo $k$ takšnemu stanju. Z njimi se je moč naučiti postopkov, prav lahko pa se je z njimi tudi miselno pohabiti. Podobno se godi s potrošniki. Ti naj bi bili pasivni in vodljivi.

Med tem pa se družbene elite kapitalizma, denimo v Franciji, še zmeraj izobražujejo na elitnih "grandes ecoles" tj. visokih šolah, ki so 
vzporedni sistem izobraževanja ob fakultetah, in na elitnih ameriških univerzah $z$ visoko letno šolnino. Izobraževanje na teh šolah razvija miselne procese.

Oblikovanje človeka, ki je iztrgan iz kontinuitete kulture, ki ne uporablja kritičnega mišljenja, ki posledično ne uspe oblikovati samopodobe, ni naključno dejanje. Doživljamo preobrat, kajti če $z$ izobraževanjem preoblikujemo človeka, bomo preoblikovali tudi svoje skupne družbene institucije. V nevarnosti pa niso le te institucije, $v$ nevarnosti je človek. In nič več ne bo moglo zajeziti popolnega kapitalizma, kjer bo človekova amopodoba odvisna od tega, kakšen potrošnik bo, kjer bo vse, prav vse, predmet trgovanja: čustva, kultura, narava, živa bitja in človekov domišljijski svet. ${ }^{l}$

${ }^{1}$ Kulturne stvaritve so nedavno proglasili za storitve, ki se obravnavajo tako kot blago v okvirih GATT-a, trgovinskega sporazuma, $k i$ države omejuje $v$ samostojnem urejanju pretoka blaga in storitev. Zdaj naj bi predmet takšne kodifikacije postalo še izobraževanje. 